\title{
今は結束する時
}

\section{All together now}

Nature Vol. 436 (303)/21 July 2005

国際熱核融合実験炉はフランスに建設されることが決まったが、同計画に参加する国々の間に、さほどの わだかまりは生じなかった。今、参加各国は、このプロジェクトのもとに結束しなければならない。

これで、ようやく国際熱核融合実験炉（ITER）が建設される ようだ。この国際的な核融合エネルギー実験計画の歩みは不確 かで、そこに核融合研究自体の歩みが反映されているように思 われるときすらあったが、このほど ITER 計画の参加国は、来 年から ITERの建設をフランスではじめることに原則合意した。

ITER のホスト国の技術力に疑問をさしはさむ者はいないで あろう。フランスの核技術にはすばらしい伝統があり、ITER 計画実現への強固な意志と欧州連合 (EU) 各国の強力な支持 もある。ITERの設計に関しては、技術的な問題が若干ある (Nature 2005 年 7 月 21 日号 p.318 参照) が、同計画をスター トさせる準備が整ったことを核融合研究者のほとんぞは好意的 に受けとめている。

ただし ITER 計画が実際に滑りだすまでには、重要ないくつ かの詳細部分を解決して扔く必要がある。たとえば、同計画の ための資金確保の問題がある。ほとんぞの参加国が、まだ用意 できていない。それに、資金のかなりの部分は、既存の核融合 研究プロジェクトの資金を削って、捻出される可能性が高い。 打抢まかにいえば、 EU が建設費の半分を支出し、残りの 5 か 国（日本、米国、ロシア、中国、韓国）が、10\%ずつ負担す ることになっている。また、日本で建設予定の第 2 施設の中身 も決まっていない。

一部の参加国では、ITER が国内の重要研究プロジェクトと かち合っている。たとえば米国では、ブッシュ政権が、ITER の年間建設費 5000 万ドル（約 55 億円）を既存の磁気核融合 研究予算 2 億 3000 万ドル（約 250 億円）でまかなおうとした。 当然、下院科学委員会の Sherwood Boehlert 委員長は、この ような提案は受け入れられないと警告した。もしブッシュ政 権が、エネルギー省が最優先施設に選定した ITER を心から支 持するのなら、来年 2 月に提出される 2006 年度予算案には、 ITER 関連予算が別途、計上されるだろう。

米国議会では、一部の議員が、国際的なプロジェクト自体（と くにフランスで行われるプロジェクト）に対する支援を疑問視 することはまちがいない。そ机でも米国の科学者が ITER プロ ジェクトのもとに結束すれば、少しは好意をもって他国を报い たいという願望が議会の大勢となるだろう。かつて米国では、
このようにして、スイスの大型陽子陽子衝突型加速器 (LHC) に対して、今回と金額的に近い長期的な拠出金を予算化している。 第二の問題は、建設が予定されている支援施設の夕イプの決 定と資金確保である。この第 2 プロジェクトには、材料試験セ ンター、データ解析のための計算センターと日本の核融合実験 用 JT-60 の後継装置の建設が含まれる可能性が高い。日本は、 同国内での ITER 建設を断念する見返りとして、日本が第 2 プ ロジェクトを主導することについての EU の支持を取りつけ た。日本は、このプロジェクトのリーダーに最も適任で、設備 や知識も最も備わっている。ITER建設では主導権を取れなかっ たが、第 2 プロジェクトでは真のリーダーとして進み出るべき である。他の参加国は、日本がこの役割を果たすことを支持す ベきである。

このプロジェクトの中で、最も高額であり、核融合エネルギー に向けた国際的な研究の進展の観点から最も有益なのが、材料 試験に使用される中性子源であろう。実用核融合炉での使用が 考えられているステンレス鋼や他の合金の結晶構造は、中性子 の衝撃によって急速に劣化すると予測されている。これまでは、 適切な中性子束を提供できる試験施設がなかったため、実用核 融合炉の全使用期間水わたって中性子衝撃に耐元られるような 金属やセラミックスが見つかっていない。磁気核融合研究を前 進させるためには、そのような試験施設が ITER とともに必要 なのである。

しかし研究の進展は、核融合の推進派が期待するほど速い ペースになっていない。とはいうものの、この点には、ニワト リが先か卵が先かという側面があった。すなわち、磁気核融合 研究に対する資金提供は、最も必要とされていた時期に減額さ れていたのだ。反対派は、次のような冗談をいう。核融合エネ ルギーは、50 年先の技術といわ続けてきたが、これからも ずっと 50 年先の技術だ、と。核融合技術を実現させるために は、懐疑的な立場の人々に、核融合のユニークで無限に近い潜 在力を理解させて、懐疑的な姿勢が正しいのかぞうかを考元さ せる必要があるだろう。核融合の潜在能力を疑うのなら、一度、 早起きして、日の出を拝んでみたらどうだろうか。 